\title{
COMPOSITION OF THE RIGID-LAYER OF STREPTOMYCES ANTIBIOTICUS PRODUCING PEPTIDE ANTIBIOTICS
}

\author{
Z. Ґ̌REHÁČ̌EK, M. RAMANKUTtY* and J. KAŠLÍK \\ Department of Biogenesis of Natural Products, Institute of Microbiology, \\ Czechoslovak Academy of Sciences, Praha, Czechoslovakia
}

(Received for publication April 8, 1968)

\begin{abstract}
Streptomyces antibioticus producing antimycin $\mathrm{A}$ and actinomycin did not fit in cell-wall types of aerobic actinomycetes. In addition to universal actinomycetes cell-wall components, i.e. glucosamine, muramic acid, glutamic acid and alanine, diaminopimelic acid (DAP), lysine, leucine (isoleucine), glycine, arabinose, glucose, galactose and mannose were detected as major constituents. Phase of the life-cycle influenced the distribution of serine, aspartic acid, lysine and DAP isomers. LL-DAP was found rather than meso form. MesoDAP was consistently revealed after $48 \mathrm{hr}$ incubation and not at other times, and as distinct from LL was not strict alternative with lysine. The occurrence of meso-DAP, relatively small amounts of murein glucosamine $(2.2 \sim 5.5 \%)$ and lysozyme resistance suggest a similarity to nocardiae cell-walls. Decrease of murein hexosamine was unfavourable for antimycin A yields. Variation of the murein amino acids stimulated production of actinomycin.
\end{abstract}

Our understanding of microbial cell-walls has developed rapidly with contributions from a number of laboratories. However, little information is available for groups of organisms other than bacteria. The present paper deals with the nature of cell-walls of Streptomyces antibioticus during submerged fermentation of antimycin $A$ and actinomycin. It was felt that the results might provide a sounder basis for the study of comparative biochemistry of streptomycetes and establish some relationships between cell structures and the biosynthesis of secondary metabolites.

\section{Materials and Methods}

\section{Organism and Culture Conditions}

The strain of Streptomyces antibioticus NRRL 2838 obtained from the Northern Utilization Research and Development Division, Peoria, Ill., was used in experiments. Cultivation on a rotary shaker $\left(240 \mathrm{rpm}, 5.3 \mathrm{~cm}\right.$ (2.1 in.) amplitude) was carried out at $28^{\circ} \mathrm{C}$ in flasks $(500 \mathrm{ml})$ with complex medium $(150 \mathrm{ml})$ previously described ${ }^{9)}$.

\section{Preparation of Cell-walls and Rigid-layer (R-layer)}

After incubation, the cells were kept in $0.5 \%$ formaldehyde overnight at $20^{\circ} \mathrm{C}$, collected by centrifugation and washed with $1 \% \mathrm{HCl}$ and distilled water. After treatment with ethanolic $\mathrm{KOH}(0.5 \%)$ at $28^{\circ} \mathrm{C}$ for 24 hours the cells were washed with ethyl alcohol and distilled water. The cells were disrupted by sonication in $0.3 \mathrm{M}$ sucrose solution using an MSE ultrasonic sonicator $(20 \mathrm{kc} / \mathrm{s})$ for 6 minutes. The degree of breakage was indicated by the gram stain. The unbroken cells were removed by centrifugation at $2,000 \times g$

\footnotetext{
* Present address : Antibiotics Division, Central Drug Research Institute, Lucknow, India
} 
for 20 minutes. The supernatant fluid was then centrifuged at $17,500 \times g$, the deposited crude broken cell-walls were washed three times with $0.05 \mathrm{M}$ phosphate buffer $\mathrm{pH} 7.6$ and three times with distilled water. The absence of gross cytoplasmatic materials in cellwalls was checked with the electron microscope (UPT-ČSAV, Brno).

R-Layer of the cell-walls was prepared as follows: The crude cell-walls were resuspended in a freshly prepared and filtered solution of trypsin in $0.05 \mathrm{M}$ phosphate buffer $\mathrm{pH} 7.6(0.5 \mathrm{mg} / \mathrm{ml})$ and digested at $37^{\circ} \mathrm{C}$ for 3 hours on a shaker. Trypsin was removed by washing with phosphate buffer and distilled water. The cell-walls were then subjected to the action of a freshly prepared and filtered solution of pepsin in $0.02 \mathrm{~N} \mathrm{HCl}(1 \mathrm{mg} / \mathrm{ml})$. The mixture was put on the shaker at $37^{\circ} \mathrm{C}$ overnight, then centrifuged at $17,000 \times g$ for 10 minutes and finally washed with $0.02 \mathrm{~N} \mathrm{HCl}$, distilled water and $95 \%$ ethyl alcohol. The purified R-layer preparations were freeze-dried and stored until used.

Analytical Methods

For amino acids analysis the samples were hydrolyzed in $6 \mathrm{~N} \mathrm{HCl}$ in sealed Pyrex tubes at $105^{\circ} \mathrm{C}$ for 18 hours. For amino sugars hydrolysis with $7 \mathrm{~N} \mathrm{HCl}$ at $100^{\circ} \mathrm{C}$ for 4 hours (FISCHER \& NEREL, 1955) was used. The hydrolysates were filtered, evaporated to dryness three times to remove the $\mathrm{HCl}$ and taken up in $0.3 \mathrm{ml}$ of distilled water. Amino acids were detected by electrochromatography ${ }^{10)}$, glucosamine and muramic acid by paper chromatography ${ }^{8\rangle}$. For quantitative determination of glucosamine RosenLund's method ${ }^{16)}$ was used.

Diaminopimelic acid (DAP) was identified in the samples hydrolysed with $6 \mathrm{~N} \mathrm{HCl}$ under reflux for 24 hours $^{21)}$. The washed hydrolysate $(15 \mu \mathrm{l}$ equivalent to $2.5 \mathrm{mg}$ dry $\mathrm{R}-$ layer) was applied to Whatman No. 1 paper, and one-dimensional descending chromatography was carried out by overnight irrigation with methanol-water-10 $\mathrm{N} \mathrm{HCl-pyridine}$ $(80: 17.5: 2.5: 10, \mathrm{v} / \mathrm{v})$ according to HOARE \& $\mathrm{WORK}^{7)}$. Chromatograms were dipped in ninhydrin $(0.1 \% \mathrm{w} / \mathrm{v})$ in acetone and heated for 2 minutes at $100^{\circ} \mathrm{C}$ (Rhuland et al. $)^{11)}$. The DAP spots were light olive green and on standing changed to a stable yellow color with a faint pink fluorescence under ultraviolet light. Since the chromatography did not differentiate between meso- and DD-DAP, these isomers were identified enzymatically by means. of diaminopimelic acid decarboxylase ${ }^{7}$. Crude preparations of the enzyme was obtained from Escherichia coli NCIB 8113 (CASIDA \& Baldwin) ${ }^{4)}$.

For sugars other than amino sugars samples were hydrolyzed in $2 \mathrm{~N}_{2} \mathrm{SO}_{4}$ in sealed Pyrex tubes at $100^{\circ} \mathrm{C}$ for 6 hours. The hydrolysate was neutralized with $\mathrm{BaCO}_{3}$. The precipitate of $\mathrm{BaSO}_{4}$ was centrifuged and the supernatant fluid was evaporated to dryness in vacuo. The final product was redissolved in distilled water so as to contain the sugars from $20 \mathrm{mg}$ (dry weight) of the preparation in $0.25 \mathrm{ml}$. An amount of $10 \mu \mathrm{l}$ of the hydrolysate was spotted on Whatman No. 1 paper for ascending chromatography with 3 successive runs in the solvent system $n$-butanol-acetic acid-water $(4: 1: 5)$. A standard solution mixture $(10 \mu 1)$ of sugars was spotted on the same paper for reference. The papers were dried at room temperature and sprayed with reagent containing $4 \%$ solution of $\mathrm{AgNO}_{3}$ and $5 \mathrm{~N}$ ammonia $(1: 1)$.

Susceptibility of the cell-wall material to lysis by lysozyme was determined by suspending the cell-wall preparation in $0.07 \mathrm{M}$ phosphate buffer $\mathrm{pH} 6.6$, containing $0.017 \mathrm{M} \mathrm{NaCl}$, adding egg white lysozyme $(100 \mu \mathrm{g} / \mathrm{ml})$ and incubating at $37^{\circ} \mathrm{C}$. Decrease in optical density during 2-hour incubation was determined at 20 minutes intervals by the recording spectrophotometer (Unicam SP-700). The antibiotic activity was determined by a microbiological plate method ${ }^{13)}$ using Candida albicans, SZU/44 strain, and Bacillus subtilis, FDA 6633 strain, as test organisms and antimycin $A$ and actinomycin $C$ as standards. The representative ultraviolet and visible spectra of partially purified antimycin $A$ and actinomycin ${ }^{3)}$ were examined in a spectrophotometer (Unicam SP-700). 


\section{Results}

The preparation of the R-layer ${ }^{20}$ of the submerged culture of S. antibioticus appeared free from electron dense cytoplasmatic material and has a relatively homogenous appearance without any obvious fine structure (Plate 1). Hexosamine determination revealed the presence of relatively small amounts $^{15}$ of glucosamine (Fig. 1). Evidence for the 3-O-carboxyethyl derivate of glucosamine, muramic acid, was also shown in the R-layer hydrolysates. Sugar other than aminosugars found in the investigated material included glucose, galactose, mannose and arabinose. No significant difference were found between the individual mycelia of different age in regard to the concentration of reducing sugars except for hexosamine. As shown in Fig. I the apparent decrease in the $\mathrm{R}$-layer hexosamine was reflected as unfavourable for antimycin A yields. Although the presence of glucosamine and muramic acid was a

Plate 1. Electron photomicrograph of the S. antibioticus $\mathrm{R}$-layer, shadowed with chromium at an angle 25 degrees, $20,000 \times$

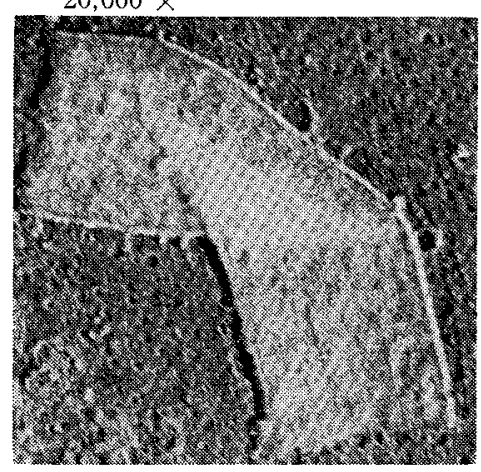

constant feature of the cell-walls, lysozyme was without action upon S. antibioticus. As was the case with whole cell the isolated cellwalls resisted dissolution by 1ysozyme.

In addition to the common cellwall amino acids, i.e. alanine, glutamic acid, glycine, serine, aspartic acid, lysine and diaminopimelic acid (DAP), leucine (isoleucine) was also found in the $S$. antibioticus R-layer. All mentioned amino acids were present in a bound form so as to be apparent only after hydrolysis. The analytical data presented in Table I, Figs. 1 and 2 indicate that at different times of cultivation the R-layer was heterogenous in respect to amino acid composition. Regarding the variation in distribution, attention can be directed to serine, aspartic acid, lysine and DAP isomers (Table $\mathrm{I}$, Fig. 2). The amino acid variation
Table 1. Amino acids in $\mathrm{R}$-layer hydrolysates of $S$. antibioticus during fermentation of antimycin $A$ and actinomycin

\begin{tabular}{c|c|c|c|c|c|c|c|c}
\hline $\begin{array}{c}\text { Time } \\
\text { (hrs) }\end{array}$ & $\begin{array}{c}\text { Leu } \\
\text { (Ileu) }\end{array}$ & Ala & Gly & Glu & Ser & Asp & Lys & DAP \\
\hline 24 & ++ & ++ & ++ & ++ & ++ & ++ & - & ++ \\
48 & + & ++ & + & ++ & ++ & + & + & ++ \\
72 & + & ++ & + & ++ & - & + & - & ++ \\
96 & + & ++ & + & ++ & - & \pm & - & ++ \\
\hline
\end{tabular}

Note : Except for isoleucine (Ileu) and diaminopimelic acid (DAP) amino acids were referred by the first three letters of their names.

++ an intensely colored spot on chromatogram; + a small definite spot; \pm doubtful; - no spot, amino acid absent.

Fig. 1. Glucosamine in R-layer of S. antibioticus during fermentation of antimycin $A$ and actinomycin

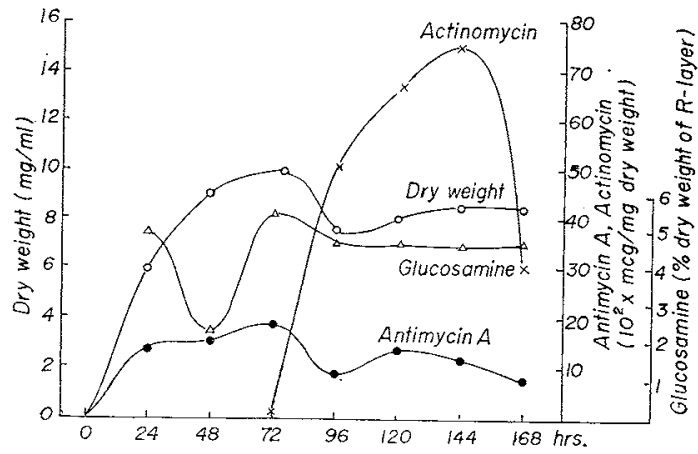


was associated with that phase of the lifecycle at which culture growth has almost ceased, lysis of the cells begun and chromopeptide actinomycin appeared in the culture medium (Fig. 1). Thus it was confirmed that the cell-wall character of young cells was altered as they became old. As to DAP, it is worth emphasizing that analysis of several separate R-layer samples gave consistent results for the content of meso isomer in 48-hour mycelium, while 24-, 72- and 96-hour samples were found to contain DAP in its LL form (Fig. 2). Crude decarboxylase preparation from Escherichia coli completely decarboxylated the DAP of 48-hour mycelium, proving the presence of meso and absence of DD isomers), and had little action on LL-DAP revealed in the above mentioned samples. DAP in its optically inactive configuration did not appear to be a strict alternative with lysine as an amino acid constituent of the R-layer.

\section{Discussion}

S. antibioticus producing antimycin A and actinomycin yielded cell-walls, the R-layer of which contained glucosamine, muramic acid, glutamic acid, alanine, diaminopimelic acid (DAP), lysine, leucine (isoleucine), glycine, arabinose, glucose, galactose and mannose. It can be concluded that the investigated cell-walls contained mucopeptides (Perkins \& RoGERS $\left.{ }^{11}\right)$, more recently called mureins (WEIDEL \& PELzER ${ }^{19)}$ ) or glycoamino-peptides $\left(\right.$ SALTON $^{18)}$ ), resembling those established in cell-walls of all bacteria so far examined $\left(\mathrm{SALTON}^{17)}\right)$. However, S. antibioticus does not fit in any of the four cell-wall types of aerobic actinomycetes considered by BECKer, LeCHEvalier \& LECHEvalieR ${ }^{2)}$ but resembles a strain of Nocardia, sp. LL-SS $1 / 5$, which is supposed to be a link between the nocardiae and streptomycetes. Relatively small amount of cell-wall glucosamine occurred in $S$. antibioticus $(2.2 \sim 5.5 \%)$ as compared with that in S. griseus $(19.9 \%)$, S. fradiae $(19.8 \%)$ or S. bobiliae $(12 \%)$. Also lysozyme resistance and occurrence of meso-DAP remind one of Nocardiae (Romano \& SOHLeR ${ }^{15}$ ); HoAre \& WORK $^{7)}$ ).

The findings obtained revealed that the cell-wall character of young cells was altered as they became old. It is reasonable to assume that phase of the life-cycle influenced not only the distribution of hexosamine, serine, aspartic acid and lysine but also the proportion of DAP isomers. The presence of meso DAP after 48 hours of incubation and not at other times was surprising. It was possible that LL-DAP might be synthetized first from precursor in the LL configuration and the meso isomer was subsequently formed by racemization. One can speculate that the conversion was catalyzed by a specific DAPracemase (AnTIA, HoARe \& WORK ${ }^{1)}$ ) as an important step in lysine biosynthesis. This might explain the fact that meso-DAP, as distinct from LL, was not a strict alternative with lysine as amino acid constituent of murein layer.

The apparent decrease in $\mathrm{R}$-layer hexosamine was reflected as unfavourable for antimy- 
cin A yields prior to the stationary phase of growth. Taking into account these data, previous results ${ }^{13)}$ and the dipeptide character of antimycin $\mathrm{A}$, a correlation might be suggested between biosynthesis-degradation processes of the cell-walls and those involved in the biosynthesis and degradation of antimycin $A$. The variation of the R-layer amino acids and concomitant production of the peptide actinomycin where culture growth has almost ceased and lysis of the cells begun tempt one to assume the lower specificity of the processes in aging cells and an important difference between the biosynthesis of actinomycin peptide and that of proteins.

\section{Acknowledgements}

The authors wish to express their thanks to H. A. LeChevalier (meso-diaminopimelic acid), Institute of Microbiology, Rutgers, The State University, New Brunswick, N. J., and to F. M. Strong (antimycin A), Department of Biochemistry, The University of Wisconsin, Madison, Wis., for kindly sending the reference samples as indicated. The skilled technical asistance of Mr. S. Š varc is, gratefully acknowledged.

\section{Literature cited}

1) Antia, M.; D. S. Hoare \& E. Work: The stereoisomers of $\alpha, \varepsilon$-diaminopimelic acid. III. Properties and distribution of diaminopimelic acid racemase, an enzyme causing interconversion of the LL and meso isomers. Biochem. J. $65: 448 \sim 458,1957$

2) Becker, B.; M. P. Lecheyalier \& H. A. Lechevalier : Chemical composition of cell-wall preparations form strains of various form-genera of aerobic actinomycetes. Appl. Microbiol. 13: $236 \sim 243,1965$

3) Camiener, G. W.; A. Dietz, A. D. Argoudelis, G. B. Whitfield, W. H. DeVries, C. M. Large: \& C. G. Sмттн: The production of two structurally unrelated antitumor agents, actinomycin and antimycin A by Streptomyces antibioticus cultures. Antimicrob. Agents Ann. $1960: 494 \sim$ 501, 1961, Plenum Press, New York

4) Casida, L. E. \& N. Y. Batdwin: Preparation of diaminopimelic acid and lysine. U. S. Pat. $2,771,391$, Nov. 20, 1965

5) DeWEy, D. L.; D. S. HoARE \& E. WorK : Diaminopimelic acid decarboxylase in cells and extracts of Escherichia coli and Aerobacter aerogenes. Biochem. J. $58: 523 \sim 531,1954$

6) Fischer, F. G. \& H. J. NebeL : Nachweis und Bestimmung von Glucosamin und Galactosamin auf Papierchromatogrammen. Z. Physiol. Chem. $302: 10 \sim 19,1955$

7) HoARE, D.S. \& E. Work : The stereoisomers of $\alpha, \varepsilon$-diaminopimelic acid. II. Their distribution in the bacterial order Actinomycetales and in certain Eubacteriales. Biochem. J. $65: 441$ $\sim 447,1957$

8) Honnung, M. : Paper chromatography of pneumococcal cell-wall hydrolysates containing glucosamine, galactosamine, muramic acid, and peptides. J. Bacteriol. $86: 1345 \sim 1346,1963$

9) Kannan, L. V.; J. Kozova \& Z. Řehičer : Biogenesis of peptide antibiotics. I. Dynamics of antimycin A biosynthesis by Streptomyces antibioticus NRRL 2838. Folia Microbiol. 13: 1 6, 1967

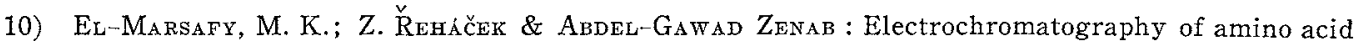
mixtures in fermentation liquors. Folia Microbiol. 8:362 369, 1963

11) Perkins, H. R. \& H. J. Rogers: The products of the partial hydrolysis of the mucopeptide from cell wall of Micrococcus lysodeikticus. Biochem. J. $72: 647 \sim 650,1959$

12) Кеніс́ек, Z. : Determination of the effectiveness of polyene type anifungal antibiotics in fermentation fluids. Folia Biol. $4: 254 \sim 255,1958$

13) К̌ REÁČEK, Z. : Some relations between the morphology and composition of the mycelium of Streptomyces erythreus and the biosynthesis of erythromycin. Folia Microbiol. $4: 326 \sim 331,1959$

14) Rhuland, L. E.; E. Work, R. F. Denman \& D. S. Hoare: The behavoir of the isomers of $\alpha, \varepsilon-$ diaminopimelic acid on paper chromatograms. J. Am. Chem. Soc. $77: 4844 \sim 4846,1955$

15) Romano, A. H. \& A. Sohler : Biochemistry of the Actinomycetales. II. A comparision of the cell wall composition of species of the genera Streptomyces and Nocardia. J. Bact. 72:865 868,1956 
16) Rosentino, B. : Quantitative determination of glucosamine. Scandinav. J. Clin. \& Lab. Investig. $8: 177 \sim 181,1956$

17) SaLton, M. R. J. : Microbial cell walls. J. Willey \& Sons, New York, 1960

18) SAItON, M. R. J. : The bacterial cell walls. Elsevier, Amsterdam, 1964

19) Weidel, W. \& H. PELzer : Bag-shaped macromolecules-a new outlook in bacteria cell walls. Adv. Enzymol. $26: 193,1964$

20) Weidel, W.; H. Frank \& H. H. Martin: The rigid layer of the cell wall of Escherichia coli strain B. J. Gen. Microbiol. $22: 158 \sim 166,1960$

21) Work, E. \& D. L. Dewey : The distribution of $\alpha$, $\varepsilon$-diaminopimelic acid among various microorganisms. J. Gen. Microbiol. $9: 394 \sim 409,1953$ 